\title{
Gender differences in first-year students' expectations towards a new engineering multidisciplinary curriculum
}

\author{
Inês Direito, Emanuela Tilley and John E Mitchell \\ UCL Centre for Engineering Education, Faculty of Engineering Sciences \\ University College London \\ London, United Kingdom \\ i.direito@ucl.ac.uk,e.tilley@ucl.ac.uk,j.mitchell@ucl.ac.uk
}

\begin{abstract}
Research on engineering first-year students' expectations and perceptions is important to understand what influences interest, achievement and persistence. This is particularly relevant when assessing the impact of new engineering education curricula. This paper reports a quantitative analysis of a pre-degree survey targeting students' expectations at the very beginning of the new Integrated Engineering Programme, which spans across the whole UCL Faculty of Engineering Sciences. Of a cohort of approximately 700 enrolled students, 309 completed the survey. Results suggest that, on graduation, both male and female students expect to have similar opportunities, such as to be able to contribute positively to the world. They also share identical learning expectations and educational experiences regarding their time studying engineering. However, results also suggest that female students were more aware of the societal impact of engineering, and less confident in their engineering specific skills.
\end{abstract}

Keywords - engineering multidisciplinary curriculum; first-year students; gender; students' expectations; self-confidence

\section{INTRODUCTION}

Over the past four years, the Faculty of Engineering Science at UCL has been implementing a multi-disciplinary curriculum review of engineering education - the Integrated Engineering Programme (IEP) - where students, from the very beginning of their degree, engage with the practical application of engineering and skills needed to undertake engineering projects effectively [1].

In order to assess the impact of the IEP in the short and long term, data collection was planned to provide evidencebased findings and support further refinement and development initiatives. The first set of data was gathered at the start of the programme, to provide a baseline level for future comparisons. Collection of baseline data, before an instructional intervention begins, is one of the most common quantitative approaches used in educational research [2].

Data are also helpful in assessing and monitoring student progress. Researchers in engineering education have taken various studies to explore and understand students' motivations, attitudes towards teaching and learning, and expectations about career outcomes. They have found that individual's perceptions and previous experiences, at the beginning of an engineering course, have a strong influence on student persistence [3][4].

The under-representation of women in engineering education and careers has raised the attention to potential gender differences. Understanding these differences would enable educators to meet the needs of all their students and create an inclusive and diverse learning environment. Studies have found that at the beginning of an engineering course, female students generally reported higher levels of anxiety, and lower levels of academic preparation than men [5].

An important variable for understanding students' experiences is self-efficacy, defined by Bandura [6] as a person's judgement of their own capacity and ability to perform in specific tasks. A strong self-efficacy has been linked to students' persistence in engineering education, for both men and women [7]. However, several studies have found that men and women differ in their self-efficacy beliefs and confidence in engineering skills, with women reporting lower statistically significant values [4][8].

This paper gives a brief overview of the major findings of the baseline data of IEP Impact Survey, with a focus on students' expectations, confidence and career intentions, and a first analysis of gender differences. It is presented as a work in progress as the first cohort of students are expected to finish their master's degree in $2017 / 18$. A post-degree survey is currently being prepared.

\section{IEP IMPACT STUDY: UNDERSTANDING STUDENTS INITIAL PERCEPTIONS AND EXPECTATIONS}

\section{A. On-line survey}

A short on-line survey was completed via Moodle by the newly enrolled year 1 students, across all engineering departments, at the beginning of their first term at UCL, in September 2014 (pre-degree survey). The main aim of this survey was to understand the initial perceptions and expectations of the students upon entering their engineering education at UCL [9].

The first set of questions in the survey asked the students to ascertain the future opportunities they seek as engineering 
graduates, as well as their own learning expectations and anticipation of the most beneficial and most enjoyable learning experiences during their time studying engineering. A second part of the survey asked the students to rate their level of agreement, using a 5-point Likert scale ( $1=$ strongly disagree; $5=$ strongly agree), on a series of statements regarding their reasons for choosing to study engineering and to study at UCL, the role of engineers, and expected career outcomes. The final section of the survey asked students to reflect on their confidence levels, ranging between 1 (not at all confident) and 5 (very confident), on a set of skills which are considered as essential to anyone pursuing a career in engineering.

\section{B. Descriptive statistics and analysis}

Of the 309 respondents of the survey, 24.6\% ( $\mathrm{N}=76)$ were female $(\mathrm{F})$, and $75.4 \%(\mathrm{~N}=233)$ were male $(\mathrm{M})$. The breakdown by domicile status was $35.3 \%$ United Kingdom, $16.2 \%$ Europe, and $48.5 \%$ Overseas (non-European countries).

For reporting purposes, the level for statistical significance was set at 0.05 . The chi-square statistic was used for testing relationships between categorical variables (e.g. multiple choices: opportunities; learning expectations; beneficial and most enjoyable educational experiences). $T$-tests were conducted to assess whether the means of two independent groups (female and male) were statistically different from each other. Phi $(\Phi)$ values and Cohen's $d$ were reported as a measure of effect size for chi-square and $t$-test analysis, respectively. Effect sizes were interpreted using Cohen's rule of thumb [10]: 0.2 as small, 0.5 as medium, 0.8 as large.

\section{RESULTS AND DISCUSSION}

\section{A. Opportunities}

Students were asked to select what opportunities would they most like their degree to offer on graduation. Most students $(61.8 \%)$ expected to be able to have a career that suits them and makes them happy. "To have expanded my knowledge, skills and attitudes in engineering and beyond" was the second most selected response $(35 \%)$. Around a quarter of students selected "To contribute positively to the world around me" (28.9\%), "To work on exciting real-world engineering projects" (26.5\%), and "To earn as much money as possible" $(25.9 \%)$.

When these responses were analyzed by gender, no statistically significant differences were found, and very small effect sizes were verified (Table I). However, the top three opportunities that female students would like to have were:

- "To be able to have a career that suits me and makes me happy"

- "To work on exciting real-world engineering projects"

- "To contribute positively to the world around me"

For male, the top three opportunities were:

- "To be able to have a career that suits me and makes me happy"
- "Expand my knowledge, skills and attitudes in engineering and beyond"

- "To earn as much money as possible"

These results may suggest that female students tended to choose people-oriented statements (real-world engineering projects; contribute positively to the world) over male's thingsoriented (expand knowledge, skills and attitudes; earn as much money as possible) [11]. Nonetheless, further analysis is needed to better understand potential differences in career preferences and intentions.

\section{TABLE I. OPPORTUNITIES}

\begin{tabular}{|l|l|l|l|l|}
\hline \multicolumn{5}{|l}{ On graduation, what opportunities would you most like your degree to offer } \\
you (Please select two responses that most closely apply to you) \\
\hline $\begin{array}{l}\text { To be able to have a career that suits } \\
\text { me and makes me happy }\end{array}$ & $59.5 \%$ & $69.7 \%$ & 0.124 & 0.116 \\
\hline $\begin{array}{l}\text { To understand a variety of career } \\
\text { options open to me }\end{array}$ & $14.2 \%$ & $17.1 \%$ & 0.759 & 0.042 \\
\hline To be able to remain in London & $5.2 \%$ & $5.3 \%$ & 0.973 & 0.013 \\
\hline $\begin{array}{l}\text { To be able to remain in the United } \\
\text { Kingdom }\end{array}$ & $1.7 \%$ & $6.6 \%$ & 0.091 & 0.125 \\
\hline To be able to work internationally & $22.4 \%$ & $21.1 \%$ & 0.169 & 0.107 \\
\hline To earn as much money as possible & $28.0 \%$ & $19.7 \%$ & 0.302 & 0.088 \\
\hline $\begin{array}{l}\text { To work on exciting real-world } \\
\text { engineering projects }\end{array}$ & $23.3 \%$ & $36.8 \%$ & 0.056 & 0.137 \\
\hline $\begin{array}{l}\text { To get the best possible graduate } \\
\text { job }\end{array}$ & $14.2 \%$ & $13.2 \%$ & 0.897 & 0.026 \\
\hline $\begin{array}{l}\text { To contribute positively to the } \\
\text { world around me }\end{array}$ & $26.7 \%$ & $34.2 \%$ & 0.373 & 0.080 \\
\hline $\begin{array}{l}\text { To be an effective and respected } \\
\text { engineer }\end{array}$ & $19.0 \%$ & $22.4 \%$ & 0.717 & 0.046 \\
\hline $\begin{array}{l}\text { To have expanded my knowledge, } \\
\text { skills and attitudes in engineering } \\
\text { and beyond }\end{array}$ & $35.8 \%$ & $32.9 \%$ & 0.688 & 0.049 \\
\hline $\begin{array}{l}\text { To meet interesting and intelligent } \\
\text { people }\end{array}$ & $15.5 \%$ & $19.7 \%$ & 0.626 & 0.055 \\
\hline
\end{tabular}

\section{B. Learning expectations}

The top five expectations of studying at UCL were "Build technical knowledge of my chosen engineering discipline" (43.7\%), "Solve real engineering problems" (34.6\%), "Learn to think like an engineer" (32\%), "Build knowledge and collect information for my future career" (30.1\%), and "Improve my communication, presentation and technical writing skills" $(27.2 \%)$.

No statistical significant differences were found between female and male students and, again, the effect sizes were very small (Table II). However, the largest difference between genders was in regards to exploring and improving design and making skills, with female students $(25 \%)$ being more likely to expect it than male $(15.5 \%)$. Female students were also more likely to expect to improve their maths and science knowledge; understand the roles and responsibilities of professional engineers and inner workings of the industry; solve real engineering problems; and get good grades. Male students were more likely to expect to learn to think like an engineer. 


\section{Most beneficial and most enjoyable educational experiences}

The three most beneficial educational experiences were considered to be "engineering team-based problem-solving" (47.9\%), "authentic engineering industry experiences" $(35.6 \%)$ and "activities and experiences to develop professional skills (e.g. leadership, team-working, communication)" (33.3\%).

On the other hand, the most enjoyable educational experiences were "engineering team-based problem-solving" (40.8\%), "engineering labs" (34.6\%), and "authentic engineering industry experience" (31.7\%).

TABLE II. LEARNING EXPECTATIONS

\begin{tabular}{|l|c|c|c|c|}
\hline \multicolumn{5}{|c|}{ What are your learning expectations of your time studying engineering here } \\
at UCL? (Please select the two responses that most closely apply to you) \\
\hline & Male & Female & $p$ & $\Phi$ \\
\hline Build technical knowledge & $42.2 \%$ & $47.4 \%$ & 0.386 & 0.079 \\
\hline Improve team-working skills & $15.9 \%$ & $14.5 \%$ & 0.870 & 0.030 \\
\hline $\begin{array}{l}\text { Improve my maths and science } \\
\text { knowledge }\end{array}$ & $17.7 \%$ & $23.7 \%$ & 0.455 & 0.071 \\
\hline $\begin{array}{l}\text { Build knowledge and information } \\
\text { for my future career }\end{array}$ & $30.2 \%$ & $30.3 \%$ & 0.806 & 0.037 \\
\hline $\begin{array}{l}\text { Explore and improve my design } \\
\text { and making skills }\end{array}$ & $15.5 \%$ & $25.0 \%$ & 0.154 & 0.110 \\
\hline $\begin{array}{l}\text { Learn how to think like an } \\
\text { engineer }\end{array}$ & $33.2 \%$ & $28.9 \%$ & 0.623 & 0.055 \\
\hline Achieve a good grade & $18.1 \%$ & $23.7 \%$ & 0.501 & 0.067 \\
\hline $\begin{array}{l}\text { Use and develop my creativity } \\
\text { skills }\end{array}$ & $19.0 \%$ & $21.1 \%$ & 0.818 & 0.036 \\
\hline Solve real engineering problems & $33.6 \%$ & $38.2 \%$ & 0.591 & 0.058 \\
\hline $\begin{array}{l}\text { Improve my communication, } \\
\text { presentation and technical writing } \\
\text { skills }\end{array}$ & $27.6 \%$ & $26.3 \%$ & 0.810 & 0.037 \\
\hline $\begin{array}{l}\text { Understand the roles and } \\
\text { responsibilities of professional } \\
\text { engineers and inner workings of } \\
\text { the industry }\end{array}$ & $17.2 \%$ & $23.7 \%$ & 0.409 & 0.076 \\
\hline
\end{tabular}

Both female and male students selected the same three most beneficial educational experiences. However, when it comes to the most enjoyable activities, female students were more likely to select:

- "Activities and experiences to develop professional skills (e.g. leadership, team-working, communication)" $(46.1 \%)$. This was only the fourth selection for male students $(22.4 \%), \mathrm{X}^{2}(2, \mathrm{~N}=309)=16.207, \mathrm{p}=0.000$; $\Phi=0.229$

- "Authentic engineering industry experiences" (35.5\%)

- "Engineering team-based problem solving" and "engineering labs" (both with 32.9\%)

For male students, the three most enjoyable activities were:

- “Engineering team-based problem-solving” (43.5\%)

- "Engineering labs" (34.9\%)

- "Authentic engineering industry experiences" (30.6\%)
D. Reasons to study at UCL, the role of engineers, and career expectations

Overall, students agreed that they are pleased to have chosen to study engineering $(M=4.20, \mathrm{SD}=0.946)$, that they can see a wide variety of job opportunities in engineering $(\mathrm{M}=$ $4.12, \mathrm{SD}=1.001)$, that they are pleased to have chosen to study engineering at $\mathrm{UCL}(\mathrm{M}=4.10, \mathrm{SD}=0.931)$ and that engineers need to understand the societal impact of their professional decisions $(\mathrm{M}=4.03, \mathrm{SD}=0.929)$.

Female students were more likely to agree with the following statements than male (Table III):

- "Engineers need to understand the societal impact of their professional decisions" $\left(\mathrm{M}_{\mathrm{Female}}=4.30, \mathrm{SD}=\right.$ $\left.0.766 ; \mathrm{M}_{\text {Male }}=3.95, \mathrm{SD}=0.943\right)$. This difference is statistically significant, $\mathrm{t}(306)=-2.970, \quad \mathrm{p}=0.003$ (small effect size, $\mathrm{d}=-0.392$ )

- "The role of engineers in solving the world's major societal and environmental challenges are undervalued" $\left(\mathrm{M}_{\text {Female }}=3.68, \mathrm{SD}=1.023 ; \mathrm{M}_{\text {Male }}=3.37, \mathrm{SD}=1.053\right)$. This difference is statistically significant, $\mathrm{t}(306)=$ $2.269, \mathrm{p}=0.024$ (small effect size, $\mathrm{d}=-0.300$ )

\section{E. Confidence in skills and abilities} skills:

Overall, students were more confident in the following

- "Working effectively within a diverse and multidisciplinary team of people", $\mathrm{M}=3.80, \mathrm{SD}=0.887$

- "Solving technical engineering problems and performing calculations", $\mathrm{M}=3.67, \mathrm{SD}=0.901$

- "Working with engineers from other disciplines and supporting each other to reach project goals", $M=3.63$, $\mathrm{SD}=0.922$

And less confident in:

- "Solving ill-defined real-world problems", $\mathrm{M}=3.06$, $\mathrm{SD}=0.850$

- "Designing and building an effective prototype", $\mathrm{M}=$ $3.14, \mathrm{SD}=0.923$

Male students rated their confidence in all the skills and abilities higher than female (Table IV).

Significant statistical differences werefound in the following three statements:

- "Solving technical engineering problems and performing calculations", $\mathrm{M}_{\text {Male }}=3.75, \mathrm{SD}=0.799$; $\mathrm{M}_{\mathrm{Female}}=3.47, \mathrm{SD}=1.101 . \mathrm{t}(306)=2.020, \mathrm{p}=0.046$ (small effect size, $\mathrm{d}=0.313$ )

- "Making intelligent estimates of size, scale and quantity using your engineering knowledge" $\mathrm{M}_{\text {Male }}=3.40, \mathrm{SD}=$ 0.837; $\mathrm{M}_{\text {Female }}=3.13, \mathrm{SD}=0.943 . \mathrm{t}(306)=2.358, \mathrm{p}=$ 0.019 (small effect size, $\mathrm{d}=0.312$ ) 
TABLE III. REASONS TO STUDY AT UCL, THE ROLE OF ENGINEERS, AND CAREER EXPECTATIONS

To what extent do you agree or disagree with the following statements considering the following values (1. Strongly disagree 2. Disagree 3. Neither agree nor disagree 4. Agree 5. Strongly agree)

\begin{tabular}{|c|c|c|c|c|c|}
\hline & $\begin{array}{c}\text { Male } \\
M \\
(S D) \\
\end{array}$ & $\begin{array}{c}\text { Female } \\
M \\
(S D)\end{array}$ & $\Delta M$ & t-test & $d$ \\
\hline $\begin{array}{l}\text { The prospect of } \\
\text { hands-on } \\
\text { learning } \\
\text { attracted me to } \\
\text { UCL } \\
\text { Engineering }\end{array}$ & $\begin{array}{l}3.67 \\
(0.95)\end{array}$ & $\begin{array}{l}3.72 \\
(0.92)\end{array}$ & -0.05 & $\begin{array}{l}t(306)=-0.413 \\
p=0.680\end{array}$ & -0.055 \\
\hline $\begin{array}{l}\text { I am pleased } \\
\text { that I chose to } \\
\text { study } \\
\text { engineering }\end{array}$ & $\begin{array}{l}4.23 \\
(0.94)\end{array}$ & $\begin{array}{l}4.14 \\
(0.95)\end{array}$ & 0.09 & $\begin{array}{l}t(306)=0.674 \\
p=.501\end{array}$ & 0.089 \\
\hline $\begin{array}{l}\text { I am pleased } \\
\text { that I chose to } \\
\text { study } \\
\text { engineering at } \\
\text { UCL }\end{array}$ & $\begin{array}{l}4.11 \\
(0.93)\end{array}$ & $\begin{array}{l}4.11 \\
(0.93)\end{array}$ & 0 & $\begin{array}{l}t(306)=0.020 \\
p=0.984\end{array}$ & 0.003 \\
\hline $\begin{array}{l}\text { The role of } \\
\text { engineers in } \\
\text { solving the } \\
\text { world's major } \\
\text { societal and } \\
\text { environmental } \\
\text { challenges is } \\
\text { undervalued }\end{array}$ & $\begin{array}{l}3.37 \\
(1.05)\end{array}$ & $\begin{array}{l}3.68 \\
(1.02)\end{array}$ & -0.31 & $\begin{array}{l}\mathrm{t}(306)=-2.269 \\
\mathrm{p}=0.024\end{array}$ & -0.300 \\
\hline $\begin{array}{l}\text { Engineers need } \\
\text { to understand } \\
\text { the societal } \\
\text { impact of their } \\
\text { professional } \\
\text { decisions }\end{array}$ & $\begin{array}{l}3.95 \\
(0.94)\end{array}$ & $\begin{array}{l}4.30 \\
(0.77)\end{array}$ & -0.35 & $\begin{array}{l}\mathrm{t}(306)=-2.970 \\
\mathrm{p}=0.003\end{array}$ & -0.392 \\
\hline $\begin{array}{l}\text { I can see a wide } \\
\text { variety of job } \\
\text { opportunities } \\
\text { open to me in } \\
\text { engineering }\end{array}$ & $\begin{array}{l}4.13 \\
(1.00)\end{array}$ & $\begin{array}{l}4.09 \\
(1.01)\end{array}$ & 0.04 & $\begin{array}{l}t(306)=0.313 \\
p=0.754\end{array}$ & 0.041 \\
\hline $\begin{array}{l}\text { I would like to } \\
\text { follow a career } \\
\text { in engineering } \\
\text { and contribute } \\
\text { to engineering } \\
\text { for the future }\end{array}$ & $\begin{array}{l}3.85 \\
(1.02)\end{array}$ & $\begin{array}{l}3.84 \\
(1.03)\end{array}$ & 0.01 & $\begin{array}{l}t(306)=0.084 \\
p=0.933\end{array}$ & 0.011 \\
\hline $\begin{array}{l}\text { My degree will } \\
\text { give me a wide } \\
\text { variety of job } \\
\text { opportunities in } \\
\text { areas outside } \\
\text { engineering }\end{array}$ & $\begin{array}{l}3.88 \\
(1.03)\end{array}$ & $\begin{array}{l}4.07 \\
(0.96)\end{array}$ & -0.19 & $\begin{array}{l}t(306)=-1.355 \\
p=0.176\end{array}$ & -0.179 \\
\hline
\end{tabular}

- "Applying your technical engineering knowledge to real problems" $\mathrm{M}_{\text {Male }}=3.52, \mathrm{SD}=0.858 ; \mathrm{M}_{\text {Female }}=3.25, \mathrm{SD}$ $=0.981 . \mathrm{t}(306)=2.310, \mathrm{p}=0.022$ (small effect size, $\mathrm{d}$ $=0.305)$.

\section{DISCUSSION}

The survey's results suggest that both female and male students had similar expectations regarding their learning and outcomes, although female tended to consider activities and experiences to develop professional skills (such as leadership, team-working and communication) more enjoyable than their male counterparts.
TABLE IV. CONFIDENCE

How confident are you in your current skills and ability to do the following considering the values [1.0\% (not at all confident) $2.20 \% 3.40 \% 5.100 \%$ (very confident)]

\begin{tabular}{|c|c|c|c|c|c|}
\hline & $\begin{array}{c}\text { Male } \\
\text { M } \\
(S D)\end{array}$ & $\begin{array}{c}\text { Female } \\
M \\
(S D)\end{array}$ & $\Delta M$ & t-test & $d$ \\
\hline $\begin{array}{l}\text { Solving ill- } \\
\text { defined real- } \\
\text { world problems }\end{array}$ & $\begin{array}{l}3.07 \\
(0.84)\end{array}$ & $\begin{array}{l}3.03 \\
(0.90)\end{array}$ & 0.04 & $\begin{array}{l}t(306)=-0.417 \\
p=0.677\end{array}$ & 0.055 \\
\hline $\begin{array}{l}\text { Developing } \\
\text { innovative and } \\
\text { creative } \\
\text { engineering ideas }\end{array}$ & $\begin{array}{l}3.37 \\
(0.87)\end{array}$ & $\begin{array}{l}3.26 \\
(0.90)\end{array}$ & 0.11 & $\begin{array}{l}t(306)=0.925 \\
p=0.356\end{array}$ & 0.122 \\
\hline $\begin{array}{l}\text { Working } \\
\text { effectively within } \\
\text { a diverse and } \\
\text { multi- } \\
\text { disciplinary team } \\
\text { of people }\end{array}$ & $\begin{array}{l}3.82 \\
(0.89)\end{array}$ & $\begin{array}{l}3.75 \\
(0.84)\end{array}$ & 0.07 & $\begin{array}{l}t(306)=0.634 \\
p=0.527\end{array}$ & 0.084 \\
\hline $\begin{array}{l}\text { Solving technical } \\
\text { engineering } \\
\text { problems and } \\
\text { performing } \\
\text { calculations }\end{array}$ & $\begin{array}{l}3.75 \\
(0.80)\end{array}$ & $\begin{array}{l}3.47 \\
(1.10)\end{array}$ & 0.28 & $\begin{array}{l}\mathrm{t}(306)=2.020 \\
\mathrm{p}=0.046\end{array}$ & 0.313 \\
\hline $\begin{array}{l}\text { Designing and } \\
\text { building an } \\
\text { effective } \\
\text { prototype }\end{array}$ & $\begin{array}{l}3.20 \\
(0.94)\end{array}$ & $\begin{array}{l}2.93 \\
(0.84)\end{array}$ & 0.27 & $\begin{array}{l}\mathrm{t}(306)=2.211 \\
\mathrm{p}=0.028\end{array}$ & 0.292 \\
\hline $\begin{array}{l}\text { Making } \\
\text { intelligent } \\
\text { estimates of size, } \\
\text { scale and } \\
\text { quantity using } \\
\text { your engineering } \\
\text { knowledge }\end{array}$ & $\begin{array}{l}3.40 \\
(0.84)\end{array}$ & $\begin{array}{l}3.13 \\
(0.94)\end{array}$ & 0.27 & $\begin{array}{l}\mathrm{t}(306)=2.358 \\
\mathrm{p}=0.019\end{array}$ & 0.312 \\
\hline $\begin{array}{l}\text { Applying your } \\
\text { technical } \\
\text { engineering } \\
\text { knowledge to } \\
\text { real problems }\end{array}$ & $\begin{array}{l}3.52 \\
(0.86)\end{array}$ & $\begin{array}{l}3.25 \\
(0.98)\end{array}$ & 0.27 & $\begin{array}{l}\mathrm{t}(306)=2.310 \\
\mathrm{p}=0.022\end{array}$ & 0.305 \\
\hline $\begin{array}{l}\text { Working in a } \\
\text { professional real- } \\
\text { world } \\
\text { engineering } \\
\text { setting }\end{array}$ & $\begin{array}{l}3.32 \\
(0.99)\end{array}$ & $\begin{array}{l}3.07 \\
(1.09)\end{array}$ & 0.25 & $\begin{array}{l}t(306)=1.888 \\
p=0.060\end{array}$ & 0.250 \\
\hline $\begin{array}{l}\text { Presenting my } \\
\text { ideas to others in } \\
\text { a clear and } \\
\text { engaging way }\end{array}$ & $\begin{array}{l}3.45 \\
(1.03)\end{array}$ & $\begin{array}{l}3.38 \\
(0.91)\end{array}$ & 0.07 & $\begin{array}{l}t(306)=0.536 \\
p=0.592\end{array}$ & 0.071 \\
\hline $\begin{array}{l}\text { Interacting with } \\
\text { clients to provide } \\
\text { a technical } \\
\text { solution that suits } \\
\text { their needs, } \\
\text { solves their } \\
\text { problem and help } \\
\text { them reach their } \\
\text { goals }\end{array}$ & $\begin{array}{l}3.24 \\
(0.96)\end{array}$ & $\begin{array}{l}3.22 \\
(1.00)\end{array}$ & 0.02 & $\begin{array}{l}\mathrm{t}(306)=0.104 \\
\mathrm{p}=0.917\end{array}$ & 0.014 \\
\hline $\begin{array}{l}\text { Working with } \\
\text { engineers from } \\
\text { other disciplines } \\
\text { and supporting } \\
\text { each other to } \\
\text { reach project } \\
\text { goals }\end{array}$ & $\begin{array}{l}3.65 \\
(0.92)\end{array}$ & $\begin{array}{l}3.61 \\
(0.91)\end{array}$ & 0.04 & $\begin{array}{l}t(306)=0.339 \\
p=0.735\end{array}$ & 0.045 \\
\hline
\end{tabular}

Results also suggest that female students were more aware of the societal impact of engineering, and less confident in their engineering specific skills. 
A post-degree survey is currently being analyzed to look at the impact of the programme on students' confidence and career plans after 4 years of study at UCL, as well as the analysis of focus groups sessions carried out with IEP and nonIEP students. This will allow a mixed-methods analysis of students' perceptions and experiences, and a further research on gender. In addition, two longitudinal studies are currently being established. One will keep track of students after graduation through an engineering alumni platform. The other will follow undergraduate female students throughout their degree focusing on the development of self-efficacy.

\section{REFERENCES}

[1] S. Bains, J. E. Mitchell, A. Nyamapfene, and E. Tilley, "Work in progress: Multi-displinary curriculum review of engineering education. UCL's integrated engineering programme," IEEE Glob. Eng. Educ. Conf. EDUCON, vol. 2015-April, no. March, pp. 844-846, 2015.

[2] B. M. Moskal, T. Reed, and S. A. Strong, "Quantitative and Mixed Methods: Approaches and Limitations," in Cambridge Handbook of Engineering Education Research, 2014, pp. 519-533.

[3] R. M. Felder and R. Brent, "Understanding Student Differences," J. Eng. Educ., vol. 94, no. 1, pp. 57-72, 2005.

[4] B. D. Jones, M. C. Paretti, S. F. Hein, and T. W. Knott, "An Analysis of Motivation Constructs with First-Year Engineering Students:
Relationships Among Expectancies, Values, Achievement, and Career Plans," J. Eng. Educ., vol. 99, no. 4, pp. 319-336, 2010.

[5] R. M. Felder, G. N. Felder, M. Mauney, C. E. Hamrin, and E. J. Dietz, "A Longitudinal Study of Engineering Student Performance and Retention. III. Gender Differences in Student Performance and Attitudes," J. Eng. Educ., vol. 84, no. 2, pp. 151-163, 1995.

[6] A. Bandura, "Self-efficacy: Toward a Unifying Theory of Behavioral Change," Psychol. Rev., vol. 84, no. 2, pp. 191-215, 1977.

[7] R. M. Marra, K. A. Rodgers, D. Shen, and B. Bogue, "Women Engineering Students and Self-Efficacy: A Multi-Year, Multi-Institution Study of Women Engineering Student Self- Efficacy," J. Eng. Educ., vol. 98, no. 1, pp. 27-38, 2009.R. Su, J. Rounds, and P. I. Armstrong, "Men and things, women and people: a meta-analysis of sex differences in interests.," Psychol. Bull., vol. 135, no. 6, pp. 859-884, 2009.

[8] M. Besterfield-Sacre, M. Moreno, L. J. Shuman, and C. J. Atman, "Gender and Ethnicity Differences in Freshmen Engineering Student Attitudes: A Cross- Institutional Study," J. Eng. Educ., vol. 90, no. 4, pp. 477-489, 2001.E.

[9] Tilley and J. E. Mitchell, "Sense of achievement: Initial evaluation of an Integrated Engineering design cornerstone module," ISEC 2015 - 5th IEEE Integr. STEM Educ. Conf., pp. 114-120, 2015.

[10] J. Cohen, Statistical Power Analysis for the Behavioral Sciences, 2nd ed. New York: Lawrence Erlbaum Associates, 1988.

[11] R. Su, J. Rounds, and P. I. Armstrong, "Men and things, women and people: a meta-analysis of sex differences in interests.," Psychol. Bull., vol. 135 , no. 6 , pp. 859-884, 2009. 